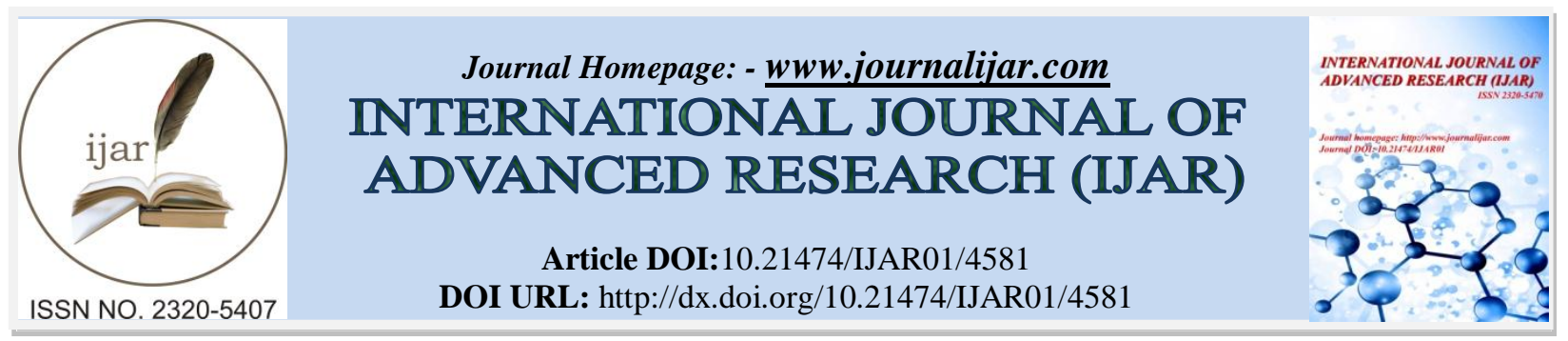

RESEARCH ARTICLE

\title{
SOCIO ECONOMIC PROFILE OF THE WOMEN PRI REPRESENTATIVES IN ODISHA: A STUDY OF BALASORE AND MAYURBHANJ DISTRICTS.
}

Laxmidhar Nayak and Prof. Dr. Shyamsundar Acharya.

\section{Manuscript Info}

Manuscript History

Received: 23 April 2017

Final Accepted: 25 May 2017

Published: June 2017

Key words:-

Awareness, Empowerment, Governance,

Knowledge, Panchayati Raj Institutions,

Participation, Women.

\section{Abstract}

Panchayati Raj Institutions are considered as a means to good governance and $73^{\text {rd }}$ Constitutional Amendment Act of 1992 became effective in the hope that it would provide better governance and give political space to the hitherto silent sections of the society like Scheduled Castes, Scheduled Tribes and women. The Present study "Socio Economic Profile of the women PRI Representatives in Odisha: A study of Balasore and Mayurbhanj Districts".was conducted on the basis of the sample of 300 women PRI respondents from 76 Gram Panchayats of 05 Sample Blocks in the tribal district of Mayurbhanj and non-tribal coastal district of Balasore in the state of Odisha. Interview schedule was used to collect primary data from these women respondents. The study revealed that most of the women representatives in the PRIs are middle aged, literate, married, joint family members, mothers of upto two children Hindus by religion with agricultural family background and drawn from low income groups etc. The patriarchal society, parochial culture, poverty and low level of education of women are largely responsible for their low quality of participation in the PRIs.

Copy Right, IJAR, 2017,. All rights reserved.

\section{Introduction:-}

Human development encompasses freedom, wellbeing and dignity of all people. Civilizations are measured in terms of the respect accorded to human dignity and freedom. So, one of the major components of human development is the empowerment of the people to participate and benefit from the development process. But the underlying principle should be that both men and women should enjoy equal human rights in all spheres of life-public and private. The full and complete development of a country, the welfare of the world and the cause of peace require maximum participation of women on equal terms with men in all fields (Ghali cited in Ray, 2006).

In the new millennium, in this cybernetic world of multi technology revolution, human being has reached the top ladder of development and everything has kept in changing at a geometrical progressive rate. However the movement for empowerment of women as a part of this great civilization and technological transformation has not reached that level. In India, women that constitute about half of the population of the country are seen as divine and worshipped as the embodiment of all virtues on the one hand, but still suffer from all sorts of exclusion, subordination, coercion, atrocities and above all patriarchic hegemony.

The empowerment of women in the rural politics of India has been neglected since independence. Though our country has adopted democratic system of government and women constitute about half of the total population of 
the country, still then, their participation in politics is very low. Due to various constraints they could not occupy the positions of power and assume leadership status. The participation of women in the decision making process is also very low and women have never been equal to men in terms of their representation, (Biju, 2006). Though the participation of women in rural politics has been increasing rapidly, but it is not satisfactory.

The $73^{\text {rd }}$ constitutional amendment Act 1993 may be marked as a water shed in the field of advancement of rural women constituting a stepping stone to their empowerment process in the Panchayati Raj Structure. It has opened up the windows of opportunities for women to emerge as leaders and play an effective role in the grass roots bodies. It has provided $1 / 3^{\text {rd }}$ reservation of seats for women in Panchayati Raj Institutions along with reservation of seats for SC and ST women. It has also provided for reservation of $1 / 3^{\text {rd }}$ of total number of offices of chairpersons in the Panchayats at all the levels for women. In addition to these, the Orissa Panchayati Raj Amendment Act provides that if a male member holds the chairpersons post, a woman member will occupy the vice chairman seat and vice versa.

In order to understand the phenomenon of women empowerment and to comprehend the multifaceted issues of women empowerment through participation in the Panchayati Raj Institutions from different perspectives, the study of the socio-conomic back ground of the elected women members in the elections to the PRIs is relevant. The socioeconomic back ground of the representatives has significant influence on their functioning in the PRIs. While studying socio-economic profile of the respondents, the important attributes like age, education, caste, marital status, type of family, occupation, income etc... are taken as important factors.

In India, the cultural-cum-material Patriarchy is perhaps interwoven with the world's most hierarchical social structure of caste and ethnicity. The family's caste ranking and a community's ethnic ranking, constrain women far more than men by the status hierarchy of work, confining them to certain areas or kinds of work and excluding them from certain others (Bardhan, 1985).

This piece of writing is the result of a doctoral work carried on during the period from 2007 to 2013. Primary data has been collected from a house to house survey of the 300 women sample respondents on the basis of interview with the help of a structured questionnaire. These samples have been selected from 76 Gram Panchayats of five sample blocks (Jaleswar and Oupada blocks in Balasore district and Tiring, Kuliana and Udala blocks in Mayurbhanj district) through random sampling method. The sample constituted women representatives of all the three tiers of Panchayati Raj structures in the four consecutive PRIs elections i.e. 1997, 2002, 2007 and 2012 of these five blocks.

\section{A Profile of the two Districts:-}

Balasore is a coastal district of Odisha. It is remarkably a strip of alluvia land. Agriculture is the main occupation of the people. Of late, industries are growing up very fast. The demographic profile shows 957 females per 1000 males as per 2011 census. Educationally the district is advanced. Gender wise male and female literacy rate, in accordance with 2011 census, is $87 \%$ and $72.28 \%$ respectively. Mayurbhanj is the adjoining district which is the largest district of the state area wise. The central portion of the district is covered by a range of hills. In spite of plentitude of mineral resources, the district is industrially backward and its economy is dependent on agriculture. The district has 1006 females for every 1000 males. Gender wise male and female literacy rate of the district, as per 2011 census, is $73.76 \%$ and $52.71 \%$ respectively.

\section{Age Component:-}

Age is a significant variable influencing the degree of participation of women in rural politics. The old can not work efficiently while the children are not eligible to enter into politics. So, in general, the young and middle aged women can be expected to participate actively in any institution. In a study on Andhra Pradesh, it has been reported that the young women form a majority in the ordinary Samitis and the middle aged women form a majority in the advanced Samitis (Manikyamba, 1989). In this research work, the members of the sample have been grouped into three categories i.e. young aged (18-30 years), middle aged (31-45 years) and aged (above 45 years). The structure of the sample women on the basis of their age composition is presented in the following table.

Table 1:- Age wise composition of the sample respondents

\begin{tabular}{|l|l|l|l|l|l|}
\hline Nameof the Districts & Name of the Blocks & $18-30$ years & $31-45$ years & Above 45 years & Total \\
\hline Balasore & Oupada & $13(26)$ & $\mathbf{3 2}(64)$ & $5(10)$ & $50(100)$ \\
\hline
\end{tabular}




\begin{tabular}{|l|l|l|l|l|l|}
\hline & Jaleswar & $29(\mathbf{2 9})$ & $\mathbf{6 0}(\mathbf{6 0})$ & $\mathbf{1 1}(\mathbf{1 1})$ & $\mathbf{1 0 0}(\mathbf{1 0 0})$ \\
\hline \multirow{5}{*}{ Mayurbhanj } & Udala & $\mathbf{1 5}(\mathbf{3 0})$ & $\mathbf{2 8}(\mathbf{5 6})$ & $\mathbf{7}(\mathbf{1 4})$ & $\mathbf{5 0}(\mathbf{1 0 0})$ \\
\cline { 2 - 6 } & Kuliana & $\mathbf{1 8}(\mathbf{3 0})$ & $\mathbf{3 4}(\mathbf{5 6 . 6 6})$ & $\mathbf{8}(\mathbf{1 3 . 3 4})$ & $\mathbf{6 0}(\mathbf{1 0 0})$ \\
\cline { 2 - 5 } & Tiring & $\mathbf{1 3}(\mathbf{3 2 . 5})$ & $\mathbf{2 1 ( 5 2 . 5 )}$ & $\mathbf{6}(\mathbf{1 5})$ & $\mathbf{4 0}(\mathbf{1 0 0})$ \\
\hline Total & $\mathbf{8 8}(\mathbf{2 9 . 3 3})$ & $\mathbf{1 7 5}(\mathbf{5 8 . 3 3})$ & $\mathbf{3 7}(\mathbf{1 2 . 3 4})$ & $\mathbf{3 0 0}(\mathbf{1 0 0})$ \\
\hline
\end{tabular}

(The figures in the parenthesis denote percentage)

(Source: Computed from primary data)

The above table depicts that out of 300 respondents, the highest number of respondents i.e.175 (58.33\%) were middle aged women between the age group of 31 to 45 years, the second highest number of respondents i.e. 88 $(29.33 \%)$ were in the young age group of 18 to 30 years and only $37(12.34 \%)$ women formed the lowest number in the aged category of above 45 years. It is clear from the table that most of the middle aged and the young aged women are visible in the power corridor of the PRIs.

\section{Caste Composition:-}

The caste system has occupied an important place in the tradition bound Indian politics and its influence in village politics can't be given less weightage. In spite of over a century of reform movement, India could not make a much tangible dent into the caste system. One finds the influence of caste in politics as a vote catching agency, (Acharya, 2008). It has been the most powerful institution in rural power structure in India and it permeates each and every aspect of rural life, (Singh, 1985). In a democratic system virtually any kind of social identity may be used as a base for mobilizing political support and it is difficult to deny that caste continues to play a major part in this regard, (Kothari, 1973).The interaction between caste and politics should be conceived as a two way process of politicization of castes and institutionalization of politics" (Sheth, 1971).

In the rural politics of Odisha, the caste system also sustains and strengthens the traditional value system and practices. With the reservation made by $73^{\text {rd }}$ constitutional Amendment Act of 1992, the communities come forward to participate in political process. A study of the castewise distribution of the sample women respondents is presented in the following table.

Table 2:- Caste wise composition of the sample respondents

\begin{tabular}{|c|c|c|c|c|c|c|}
\hline Nameof the Districts & Name of the Blocks & SC & ST & OBC & GEN & Total \\
\hline \multirow[t]{2}{*}{ Balasore } & Oupada & $8(16)$ & $6(12)$ & $26(52)$ & $10(20)$ & $50(100)$ \\
\hline & Jaleswar & $13(13)$ & $13(13)$ & $42(42)$ & $32(32)$ & $100(100)$ \\
\hline \multirow[t]{3}{*}{ Mayurbhanj } & Udala & $4(8)$ & $41(82)$ & $2(4)$ & $3(6)$ & $50(100)$ \\
\hline & Kuliana & $5(8.33)$ & $50(83.33)$ & $3(5)$ & $2(3.34)$ & $60(100)$ \\
\hline & Tiring & $3(7.5)$ & $34(85)$ & $2(5)$ & $1(2.5)$ & $40(100)$ \\
\hline \multicolumn{2}{|l|}{ Total } & 33 (11) & $144(48)$ & $75(25)$ & $48(16)$ & $300(100)$ \\
\hline
\end{tabular}

(The figures in the parenthesis denote percentage)

(Source: Computed from primary data)

The above table shows that majority of the women respondents i.e. $144(48 \%)$ belong to the Scheduled Tribes Community followed by $75(25 \%)$ number of OBC respondents, 48(16\%) number of General women respondents and only $33(11 \%)$ number of Scheduled Caste women respondents. An important thing found from the table is that highest number of women respondents are from OBC Category in the district of Balasore while it is ST Category in the district of Mayurbhanj which is the predominant one. It is because Mayurbhanj is a tribal dominated district and comes under Scheduled Areas.

\section{Educational Status:-}

Education is a vital component for the all-round development of human being. It widens the horizon of knowledge and enlarges the general outlook of a person. It is considered as an ornament of women while its utility is not recognized (Mathur, 1987). The higher is the level of education, the greater, perhaps, is political competence, interests, responsibility, self-confidence and articulateness (Acharya, 2008). An educated woman is considered important not only from socio-economic point of view but also from the nation's point of view. Illiteracy and low education, normally, prevents women members from assuming responsibilities. The illiterates and uninformed women members become easy prey to unscrupulous elements (Sinha, 2005). 
The constitution of India does not specify any educational qualification for contesting the membership of the PRIs, though, the guidelines enumerated in the OdishaPanchayat Manual say that a representative of the PRIs must be a literate. The educational background of the sample women respondents for this research work has been depicted in the following table.

Table 3:- Educational status of the sample respondents

\begin{tabular}{|c|c|c|c|c|c|c|}
\hline Nameof the Districts & $\begin{array}{l}\text { Name of the } \\
\text { Blocks }\end{array}$ & $\begin{array}{l}\text { Upto } \\
\text { Primary }\end{array}$ & $\begin{array}{l}\text { Middle } \\
\text { English level }\end{array}$ & H.S.C & Above H.S.C & Total \\
\hline \multirow[t]{2}{*}{ Balasore } & Oupada & $10(20)$ & $16(32)$ & $18(36)$ & $6(12)$ & $50(100)$ \\
\hline & Jaleswar & $21(21)$ & $28(28)$ & $38(38)$ & $13(13)$ & $100(100)$ \\
\hline \multirow[t]{3}{*}{ Mayurbhanj } & Udala & $14(28)$ & $17(34)$ & $16(32)$ & $3(6)$ & $50(100)$ \\
\hline & Kuliana & $17(28.34)$ & $22(36.66)$ & $18(30)$ & $3(5)$ & $60(100)$ \\
\hline & Tiring & $18(45)$ & $13(32.5)$ & $8(20)$ & $1(2.5)$ & $40(100)$ \\
\hline Total & $80(26.66)$ & $96(32)$ & $98(32.67)$ & $26(8.67)$ & $300(100)$ & \\
\hline
\end{tabular}

(The figures in the parenthesis denote percentage)

(Source: Computed from primary data)

The above table displays that all the sample women respondents are literate. It is found that $26.66 \%$ of the sample i.e. 80 women representatives out of 300 are educated upto primary level. It means they are just literate (those who are capable of writing their names only). Secondly, 32\% of the sample i.e. 96 women have passed the Middle English standard, but below matriculation. 32.66\% of the sample women i.e. 98 women have passed matriculation and only $8.66 \%$ of the sample women i.e. 26 women are above the Higher Secondary level of educational background. It is marked from the table that the matriculates and above Higher secondary level women are found more in the district of Balasore than in Mayurbhanj district. As a whole, it is observed that as the number of women with higher education is few in the PRIs, it is definitely an issue and challenge for the nation's growth in a positive way. Therefore, education for the women in PRIs is highly essential for their empowerment and effective participation in rural politics so that they should understand the problems of rural people and perform their duties properly.

\section{Marital Status:-}

Marital status of women representatives is an important barometer to assess the real empowerment of women in rural politics. Normally, unmarried girls in the rural areas are not allowed by their parents to take active part in rural politics because of their conservative attitude. Secondly, married women are not easily permitted by their in-laws and husbands for active participation in rural politics. The following table reveals the data relating to the marital status of the sample women respondents in the PRIs.

Table 4:- Marital status of the sample respondents

\begin{tabular}{|c|c|c|c|c|c|}
\hline $\begin{array}{l}\text { Name of the } \\
\text { Districts }\end{array}$ & $\begin{array}{l}\text { Name of the } \\
\text { Blocks }\end{array}$ & Married & Unmarried & $\begin{array}{l}\text { Single women (Widows } \\
\text { and divorced) }\end{array}$ & Total \\
\hline \multirow[t]{2}{*}{ Balasore } & Oupada & $44(88)$ & $4(8)$ & $2(4)$ & $50(100)$ \\
\hline & Jaleswar & $86(86)$ & $8(8)$ & $6(6)$ & $100(100)$ \\
\hline \multirow[t]{3}{*}{ Mayurbhanj } & Udala & $42(84)$ & $6(12)$ & $2(4)$ & $50(100)$ \\
\hline & Kuliana & $52(86.66)$ & $5(8.34)$ & $3(5)$ & $60(100)$ \\
\hline & Tiring & $31(77.5)$ & $8(20)$ & $1(2.5)$ & $40(100)$ \\
\hline \multicolumn{2}{|l|}{ Total } & $255(85)$ & $31(10.33)$ & $14(4.67)$ & $300(100)$ \\
\hline
\end{tabular}

(The figures in the parenthesis denote percentage)

(Source: Computed from primary data)

The table reveals that married women representatives are the largest in number i.e. $255(85 \%)$, participating in the Panchayati Raj Institutions. This shows the chances of married women to enter into rural politics are brighter than the unmarried and single women. Married women representatives in Balasore district are 130 in number which is nearly equal to that of Mayurbhanj districti.e.125 in number. They enjoy greater physical safety and they are assured help and co-operation of their husbands and other members of their families. The second highest group of women representatives in the PRIs is the unmarried group of ladies i.e. 31 which constitute only $10.33 \%$ of the total. More number of unmarried women in the PRIs are found in Mayurbhanj district than Balasore district. Thus the unmarried 
girls are not encouraged to enter into rural politics as they are fully dependent upon their parents who don't allow them to be exposed to rural politics because of their future marriage prospects. The parents are very conservative in out look about their character. But if unmarried girls are motivated to take an active role in politics, women can gradually be inducted to grassroots level politics so as to enable them to make concrete contributions to women's development in rural areas (Bhaskar, 1997). The investigation reveals that the lowest number of women PRI representatives belongs to the third category of single women group i.e. 14 respondents consisting of widows and separated which constitut only $4.66 \%$ of the total.

Type of family:-

The nature of family plays an important role in the process of empowerment of women in rural politics. There are two types of families normally found in Indian society viz. nuclear family and joint family. Nuclear family consists of only father, mother and their children. The nuclear family is, the symbol of modernization (Acharya, 2008). On the other hand, joint family comprises of father, mother, their children and uncles, aunts, their children and their grandchildren etc. living under one roof, eating food cooked in one kitchen, holding property in common, (Karve, 1968). The chances of intervention in the independence of women are greater in large and joint families. The joint families are marked by authoritarian setup in Indian society. Hence the position of the female members in such families is reduced to a subordinate position. Hence, the modern educated women prefer nuclear families where they can enjoy greater freedom. The rate of participation of women representatives in PRIs is expected to be less from the joint family. In this context the following table gives a clear cut picture about the type of family involved in the PRIs.

Table 5:- Type of family of the sample respondents

\begin{tabular}{|c|c|c|c|c|c|}
\hline $\begin{array}{l}\text { Nameof the } \\
\text { Districts }\end{array}$ & $\begin{array}{l}\text { Name of the } \\
\text { Blocks }\end{array}$ & Joint family & Nuclear family & Single member family & Total \\
\hline \multirow[t]{2}{*}{ Balasore } & Oupada & $28(56)$ & $21(42)$ & $1(2)$ & $50(100)$ \\
\hline & Jaleswar & $62(62)$ & 36 (36) & $2(2)$ & $100(100)$ \\
\hline \multirow[t]{3}{*}{ Mayurbhanj } & Udala & $23(46)$ & $27(54)$ & - & $50(100)$ \\
\hline & Kuliana & 25 (41.67) & $34(56.67)$ & $1(1.66)$ & $60(100)$ \\
\hline & Tiring & $21(52.5)$ & $18(45)$ & $1(2.5)$ & $40(100)$ \\
\hline \multicolumn{2}{|l|}{ Total } & $159(53)$ & $136(45.33)$ & $5(1.67)$ & $300(100)$ \\
\hline
\end{tabular}

(The figures in the parenthesis denote percentage)

(Source: Computed from primary data)

The above table reveals that out of 300 women respondents, 159 i.e. $53 \%$ respondents, the highest number of respondents belong to joint families while 136 i.e. $45.33 \%$ respondents live with their husbands and children or only with their children. Only 5 i.e. $1.67 \%$ respondents live as single member families as they have no one to live with them and they told that they have entered into politics to spend their time for the welfare of rural women. The study reveals that the incidence of joint families is the highest among the sample women respondents and it is slightly more than the women drawn from the nuclear family. The researcher found that most respondents in Balasore district were staying with their parents and brothers jointly because of requirement of agriculture, financial support of each other in the family and orthodox hierarchical social structure and social beliefs. The case is reverse in the case of the tribals in the district of Mayurbhanj. It was found that most respondents i.e. 79 were from the nuclear families because of the fact that the tribals have adopted a usual practice of staying separate after their marriage or after giving birth to one or two children.

\section{Number of Children:-}

The number of children born to a woman assumes greater importance in the context of contesting PR elections and holding positions in the PRIs. The size of the family and number of children, count a lot in everyone's life (Acharya, 2008). The limited size of family can help to create conditions in which happier families can grow and parents can give their children the due care (Thakur, 1981).

Another emerging issue is the declaration of state Government to make persons with more than two children ineligible for contesting ZillaParishad election, (The Samaj, 1994). It is a fact that a mother of a lot of children can not take part in politics more effectively than a mother of two children only. The following table shows the number of issues of PRI representatives drawn either from nuclear or joint families. 
Table 6:- Norm of child of the sample respondents

\begin{tabular}{|c|c|c|c|c|c|}
\hline $\begin{array}{l}\text { Nameof the } \\
\text { Districts }\end{array}$ & $\begin{array}{l}\text { Name of the } \\
\text { Blocks }\end{array}$ & $\begin{array}{l}\text { More than two } \\
\text { children }\end{array}$ & $\begin{array}{ll}\text { Upto } & \text { two } \\
\text { children } & \end{array}$ & No child & Total \\
\hline \multirow{2}{*}{ Balasore } & Oupada & $6(12)$ & $41(82)$ & $3(6)$ & $50(100)$ \\
\hline & Jaleswar & $13(13)$ & $79(79)$ & $8(8)$ & $100(100)$ \\
\hline \multirow[t]{3}{*}{ Mayurbhanj } & Udala & $5(10)$ & $39(78)$ & $6(12)$ & $50(100)$ \\
\hline & Kuliana & $9(15)$ & 44 (73.33) & $7(11.67)$ & $60(100)$ \\
\hline & Tiring & $8(20)$ & $28(70)$ & $4(10)$ & $40(100)$ \\
\hline \multicolumn{2}{|l|}{ Total } & $41(13.66)$ & $231(77)$ & $28(9.34)$ & $300(100)$ \\
\hline
\end{tabular}

(The figures in the parenthesis denote percentage)

(Source: Computed from primary data)

The above table depicts that 231 i.e. $77 \%$ women respondents, have only two or less than two children while 28 i.e.9.34\% women respondents have no child because such respondents belong to single woman member families. 41 respondents i.e.13.66\% women representatives have more than two children which don't appear surprising as the general picture is that the number of children born to a woman is relatively higher in rural areas. But this may make many such women representatives liable to disqualification if cases are filed and processed before the court of law against them on the ground of having more than two children which goes against the PR Acts of the state government of Odisha. To conclude it may be said that members of small families with two children are likely to take part in rural politics more effectively than those with large families having more than two children.

\section{Religion wise Distribution:-}

Religion has some practical implications in the process of empowerment of women in the grass root politics. Most of the times, it moulds a person's attitude towards his/her day to day activities in public life. Though people of all types of religion live here, still the number of Hindus constitutes the largest proportion. The result of the investigation about the type of religion of the sample respondents in the PRIs in the study area is displayed in the following table.

Table 7:- Religion-wise distribution of the sample respondents

\begin{tabular}{|c|c|c|c|c|c|}
\hline Nameof the Districts & Name of the Blocks & Hindu & Muslim & Christian & Total \\
\hline \multirow{3}{*}{ Balasore } & Oupada & $\mathbf{5 0}(\mathbf{1 0 0})$ & - & - & $\mathbf{5 0}(\mathbf{1 0 0})$ \\
\cline { 2 - 6 } & Jaleswar & $\mathbf{9 3}(\mathbf{9 3})$ & $\mathbf{7 ( 7 )}$ & - & $\mathbf{1 0 0}(\mathbf{1 0 0})$ \\
\hline \multirow{3}{*}{ Mayurbhanj } & Udala & $\mathbf{5 0}(\mathbf{1 0 0})$ & - & - & $\mathbf{5 0}(\mathbf{1 0 0})$ \\
\cline { 2 - 6 } & Kuliana & $\mathbf{6 0}(100)$ & - & - & $\mathbf{6 0}(\mathbf{1 0 0})$ \\
\cline { 2 - 6 } & Tiring & $\mathbf{4 0}(\mathbf{1 0 0})$ & - & - & $\mathbf{4 0}(\mathbf{1 0 0})$ \\
\hline & & $\mathbf{2 9 3}(\mathbf{9 7 . 6 6})$ & $\mathbf{7 ( 2 . 3 4 )}$ & - & $\mathbf{3 0 0}(\mathbf{1 0 0})$ \\
\hline
\end{tabular}

(The figures in the parenthesis denote percentage)

(Source: Computed from primary data)

The above table reveals that out of 300 respondents, 293 (97.67\%) respondents i.e. the predominant majority are Hindus and the number of Muslim respondents is only 07 (2.33\%). It is a matter of surprise that none of the respondents is a Christian. It may be because of the non existence of the Christian people in the villages. It is noticed that the small number of 07 women Muslim respondents may be because of the small proportion of Muslim population in the village level and also lack of reservation for Muslims. Thus it is clear from the table that the Hindus form the largest majority and Muslims the minority group of representatives in the PRIs in Odisha. All the Muslim Women representative are found in the district of Balasore.

\section{Occupation wise Distribution:-}

The knowledge of occupation of the women representatives is helpful largely in estimating their rate of participation in the meetings and deliberations of the PRIs. For example, in case of a woman who is a house wife or an unmarried lady, she is dependent upon her husband or parents. She can't contest in the election and participate in the Panchayat meetings without the knowledge of her husband or parents which largely affects the process of empowerment of women in PRIs. Since most of the rural women are housewives or unmarried and they are dependent upon their husbands or parents, the family occupation of the sample respondents has been taken in to account in order to have 
an idea about their socio economic background. In view of this, the occupational distribution of the sample respondents' families is presented in the following table.

Table 8:- Occupational Pattern of the families of the sample respondents

\begin{tabular}{|c|c|c|c|c|c|c|}
\hline $\begin{array}{l}\text { Name of the } \\
\text { Districts }\end{array}$ & $\begin{array}{l}\text { Name of the } \\
\text { Blocks }\end{array}$ & Agriculture & Business & $\begin{array}{l}\text { Daily wage } \\
\text { labourer }\end{array}$ & Others & Total \\
\hline \multirow{2}{*}{ Balasore } & Oupada & $34(68)$ & $8(16)$ & $3(6)$ & $5(10)$ & $50(100)$ \\
\hline & Jaleswar & $59(59)$ & $21(21)$ & $8(8)$ & $12(12)$ & $100(100)$ \\
\hline \multirow{3}{*}{ Mayurbhanj } & Udala & $29(58)$ & $7(14)$ & $9(18)$ & $5(10)$ & $50(100)$ \\
\hline & Kuliana & 34 (56.66) & $8(13.34)$ & $12(20)$ & $6(10)$ & $60(100)$ \\
\hline & Tiring & $23(57.5)$ & $6(15)$ & $8(20)$ & $3(7.5)$ & $40(100)$ \\
\hline \multicolumn{2}{|l|}{ Group Total } & $179(59.66)$ & $50(16.67)$ & $40(13.33)$ & $31(10.33)$ & $300(100)$ \\
\hline
\end{tabular}

(The figures in the parenthesis denote percentage)

(Source: Computed from primary data)

The above table reveals that more than half of the total respondents are engaged in the occupation of agriculture and their number is 179 i.e. $59.66 \%$ of the total. $40(13.34 \%)$ women belong to the category of daily wage labourer and 50 $(16.34 \%)$ women representatives belong to the family of business occupation category while 31 i.e. $10.34 \%$ women representatives belong to the category of other occupations. Thus, women belonging to the agriculture occupational group form the largest majority and dominate the PRIs in Odisha, followed by business category of women, daily wage labourers and others.

\section{Income wise Distribution:-}

Income constitutes an indispensable input in the process of empowerment of women in the PRIs. It is taken as an index of social status and influence.In India, it has been generally realized that contesting for elections and organizing campaigns require a good amount of money (Palmer, 1970). Low income, poverty conditions and wage employment of the women tend to exert adverse impact on the physical presence of women members in the meetings and deliberations of the PRIs. During investigation it was found that most of the sample women respondents had no personal income as they were housewives or unmarried and some were daily wage earners. They were dependent on their husbands or parents. Hence the family income of the sample women respondents has been taken into account in this study to know their socio economic background. The family income has been worked out on the basis of the gross annual income from all sources including farming business, service etc. It has been depicted in the following table.

Table 9:- Income wise distribution of the sample respondents

\begin{tabular}{|c|c|c|c|c|c|c|}
\hline $\begin{array}{l}\text { Name of the } \\
\text { Districts }\end{array}$ & $\begin{array}{l}\text { Name of } \\
\text { the Blocks }\end{array}$ & $\begin{array}{l}\text { Upto } \\
\text { Rs 30,000/- }\end{array}$ & $\begin{array}{l}\operatorname{Rs} 30,000 /- \text { to } \\
\operatorname{Rs} 40,000 /-\end{array}$ & $\begin{array}{l}\operatorname{Rs} 40,000 /- \text { to } \\
\operatorname{Rs} 50,000 /-\end{array}$ & $\begin{array}{l}\text { Above } \\
\text { Rs 50,000/- }\end{array}$ & Total \\
\hline \multirow{5}{*}{ 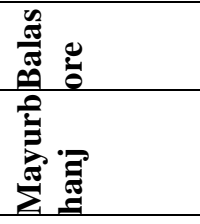 } & Oupada & $27(54)$ & $13(26)$ & $7(14)$ & $3(6)$ & $50(100)$ \\
\hline & Jaleswar & $51(51)$ & $24(24)$ & $18(18)$ & $7(7)$ & $100(100)$ \\
\hline & Udala & $32(64)$ & $9(18)$ & $6(12)$ & $3(6)$ & $50(100)$ \\
\hline & Kuliana & 37 (61.66) & $11(18.34)$ & $8(13.34)$ & $4(6.66)$ & $60(100)$ \\
\hline & Tiring & $27(67.5)$ & $7(17.5)$ & $4(10)$ & $2(5)$ & $40(100)$ \\
\hline \multicolumn{2}{|l|}{ Group Total } & $174(58)$ & $64(21.33)$ & $43(14.33)$ & $19(6.33)$ & $300(100)$ \\
\hline
\end{tabular}

(The figures in the parenthesis denote percentage)

(Source: Computed from primary data)

The above table shows that, 174 i.e. 58\% respondents belong to low level of family income having an annual income upto Rs 30,000/-. The second highest women respondents i.e. 64 (21.33\%) belong to the category having an annual income from Rs 30,000/- to Rs 40,000/-. 43 (14.33\%) women respondents belong to the category of annual income in the range from Rs 40,000/- to Rs 50,000/- only. Lastly it was found that in all the five sample Blocks, 19 respondents belong to the income group of above Rs 50,000/-. Out of these 19 respondents of high income group, many have occupied the post of ZillaParishads. Thus the table reveals that though women belonging to different types of annual income group of families participate in rural politics, the low income group of women form the largest majority and they dominate the PR bodies in Odisha. Ward members constitute the majority of the low income category. 


\section{Land Holding Pattern:-}

Land holding pattern of the families of the women representatives of the PRIs is an important attribute to assess their socio economic background. It largely determines the income status of the representatives in the PRIs. Small land holders can't devote more time towards politics compared with the large or medium types of land holders because of their financial constraints. Hence land holdings of the families of the representatives in the PRIs have larger impact in the process of participation of women representatives in the PRIs. The investigation about the land holding patterns of the sample respondents is reflected in the following table.

Table 10:- Land holding pattern of the sample respondents

\begin{tabular}{|c|c|c|c|c|c|c|c|}
\hline $\begin{array}{l}\text { Name of the } \\
\text { Districts }\end{array}$ & $\begin{array}{l}\text { Name of } \\
\text { the Blocks }\end{array}$ & Landless & $\begin{array}{l}1 \text { to } 2 \\
\text { Acres }\end{array}$ & 3 to 5 Acres & $\begin{array}{l}6 \text { to } 10 \\
\text { Acres }\end{array}$ & $\begin{array}{l}\text { More than } 10 \\
\text { Acres }\end{array}$ & Total \\
\hline \multirow[t]{2}{*}{ Balasore } & Oupada & $2(4)$ & $9(18)$ & $28(56)$ & $7(14)$ & $4(8)$ & $50(100)$ \\
\hline & Jaleswar & $3(3)$ & $18(18)$ & $54(54)$ & $16(16)$ & $9(18)$ & $100(100)$ \\
\hline \multirow[t]{3}{*}{ Mayurbhanj } & Udala & $4(8)$ & $8(16)$ & $27(54)$ & $8(16)$ & $3(6)$ & $50(100)$ \\
\hline & Kuliana & $6(10)$ & $11(18.33)$ & $29(48.33)$ & $9(15)$ & $5(8.34)$ & $60(100)$ \\
\hline & Tiring & $3(7.5)$ & $7(17.5)$ & $22(55)$ & $6(15)$ & $2(5)$ & $40(100)$ \\
\hline \multicolumn{2}{|l|}{ Group Total } & $18(6)$ & $53(17.67)$ & $160(53.33)$ & $46(15.33)$ & $23(7.67)$ & $300(100)$ \\
\hline
\end{tabular}

(The figures in the parenthesis denote percentage)

(Source: Computed from primary data)

The above table reveals that, 160 respondents i.e.53.33\% have 3 to 5 acres of land, 53 respondents i.e. $17.66 \%$ have 6 to 10 acres of land while 18 respondents i.e. $\% \%$ have no land. The landless respondents were found more in number in the tribal district of Mayurbhanj than the non-tribal coastal district of Balasore. Moreover, the table depicts that the majority of the PRI representatives are sound as far as land holding pattern is concerned. However it is to be taken with a pinch of salt that land is not owned by the female members.

Assets owned:-

Asset is an another important attribute to assess the socio-economic background of the elected representatives of the PRIs. It determines the standard of living of the representatives of the PRIs. In this study, the value of different items of assets which has been taken into account are cattle, vehicles, bicycles, motorcycles, four wheelers, tv, freeze, radio and tape recorders, cell phones, furniture sets etc. of the sample respondents. As per the investigation, the following table gives an account of the value of the assets owned by the families of the sample respondents.

Table 11:- Asset Value wise distribution of the sample respondents

\begin{tabular}{|c|c|c|c|c|c|c|c|}
\hline $\begin{array}{l}\text { Name of the } \\
\text { Districts }\end{array}$ & $\begin{array}{l}\text { Name of } \\
\text { the Blocks }\end{array}$ & $\begin{array}{l}\text { Less } \\
\text { than Rs } \\
20,000 /-\end{array}$ & $\begin{array}{l}\text { Rs } 20,000 /- \\
\text { to } \\
\text { Rs } 40,000 /-\end{array}$ & $\begin{array}{l}\text { Rs 40,000/- to } \\
\text { Rs 60,000/- }\end{array}$ & $\begin{array}{lr}\text { Rs } \quad 60,000 /- \\
\text { to } & \text { Rs } \\
80,000 /- & \end{array}$ & $\begin{array}{l}\text { Above } \\
\text { Rs } \\
\text { 80,000/- }\end{array}$ & Total \\
\hline \multirow[t]{2}{*}{ Balasore } & Oupada & $8(16)$ & $21(42)$ & $11(22)$ & $6(12)$ & $4(8)$ & $50(100)$ \\
\hline & Jaleswar & 11 (11) & $43(43)$ & $26(26)$ & $12(12)$ & $8(8)$ & $100(100)$ \\
\hline \multirow[t]{3}{*}{ Mayurbhanj } & Udala & $13(26)$ & $19(38)$ & $9(18)$ & $6(12)$ & $3(6)$ & $50(100)$ \\
\hline & Kuliana & $15(25)$ & $22(36.66)$ & $12(20)$ & $7(11.67)$ & $4(6.67)$ & $60(100)$ \\
\hline & Tiring & $9(22.5)$ & $18(45)$ & $6(15)$ & $5(12.5)$ & $2(5)$ & $40(100)$ \\
\hline \multicolumn{2}{|l|}{ Group Total } & $\begin{array}{l}56 \\
(18.67)\end{array}$ & $123(41)$ & $64(21.33)$ & $36(12)$ & $21(7)$ & $300(100)$ \\
\hline
\end{tabular}

(The figures in the Parenthesis denote percentage)

(Source: Computed from primary data)

The above table shows that, $123(41 \%)$ respondents have the asset value of Rs 20,000/- to Rs 40,000/- each. This number is the highest among all the five categories of respondents. The number of second highest category of women respondents is 64 i.e. $21.33 \%$ having an asset value of Rs 40,000/- to Rs 60,000/- followed by 56 (18.66\%) number of respondents having an asset value of uptoRs 20,000/- and 36 number of respondents i.e. $12 \%$ of total are found to have an asset value of Rs 60,000/- to Rs 80,000/- while only 21 respondents i.e. $7 \%$ of the total have an asset value of above Rs 80,000/-. The table reveals that the proportion of households decreases as the asset value increases and vice versa. For the whole sample the proportion of households owing assets worth between Rs $20,000 /$ - to $40,000 /$ - is $41 \%$, but only $7 \%$ of the sample house holds own assets valued above Rs $80,000 /-$. In the 
highest value of the assets category, Balasore has sufficient edge over the district of Mayurbhanj. The people, whether high or low income, can save and purchase their assets out of their surplus income.

\section{Conclusion:-}

To conclude, it can be said that the report of the committee on the status of women in India furnishes general profile of women in the parliament. Majority of the women candidates in parliament are drawn from relatively better off families with fairly long tradition of political socialization. On the other hand, majority of women in Panchayati Raj Institutions, thanks to reservation system in Odisha, come from low standard income agricultural families, younger in age, married having a small number of children with only functional literacy. A study of the two districts, Balasore and Mayurbhanj, dissimilar in a number of ways, confirms the above stated findings. It is to be taken note of, further, that given literacy, traditional family values, male dominance account for ineffective empowerment of women in the PRIs despite 73rd Amendment being ushered in. To realise real empowerment of women representatives, their educational and economic standard needs to be raised. This is more applicable to Mayurbhanj district of Odisha.

\section{References:-}

1. Ray, Pramod Kumar, (2006), "The Struggle for Women Equality in India: A Travel from Welfare to Empowerment", Orissa Political Science Journal, Vol. XIV, No-1, P-113.

2. Biju, M.R.,(2006),“Women's Empowerment: Politics and Policies”, Mittal Publications, New Delhi, P-29.

3. Bardhan, Kalpana, (1985), "Women's Work, Welfare and Status" in Economic and Political Weekly, Vol. XX., No- 50, December 14, P-2207.

4. Manikyamba, P., (1989), "Women in Panchayati Raj Structures", Gian Publishing House, New Delhi, P-57.

5. Acharya, S. S., (2008), "Value Orientation of Legislative Elites: A Case study of Orissa", Amadeus press, P-74.

6. Singh, R.S., (1985), "Rural Elite Entrepreneurship and Social Change", Rawat Publication, Jaipur, P-60.

7. Kothari, Rajni, (1973), "Caste in Indian Politics", Orient Longman, Bombay, P-8.

8. Sheth, D.L., (1971), "Caste and Politics: A Trend Report", Indian council of Social Science Research, New Delhi.

9. Mathur, Indu, (1987), "Women and Social Change in Rajasthan”, Print Well Publishers, Jaipur, P-96.

10. Acharya, S. S., (2008), op.cit., P-71.

11. Sinha, Archana, (2005), "PanchayatKeJariye Gram VikasmeinMahilaon Ki Bhumika", in Verma, S.B., et al (eds) "MahilaJagritiAurSashikti Karan",Avishkar Publishers, Distributors, Jaipur.

12. Bhaskar, Manu, (1997), "Women Panchayat Members in Kerala", in Economic and Political weekly, April 26, $\mathrm{P}-13$.

13. Acharya, ShyamSundar, (2008), op.cit., P-85.

14. Karve, Iravati, (1968), "Kinship Organization in India", Asia Publishing House, Bombay, P-8.

15. Acharya, ShyamSunadr, (2008), op. cit., P-83.

16. Thakur, R. N., (1981), "Elite Theory and Administrative System", Sterling Publishers, Lucknow, P-145.

17. The Samaj, (1994), Cuttack, October 23.

18. Palmer, D. Norman, (1970), "The Indian Political System", Houghton Mifflin Company, Boston, P-48. 